\title{
Fair Trade as a Community Development Initiative: Local and Global Implications
}

\section{Charity Samantha Fitzgerald}

\begin{abstract}
This paper examines fair trade as a community development initiative that challenges unjust global trading conditions. On a local level, fair trade aims to create a sustainable livelihood for farmers, to strengthen agricultural cooperatives, and to fund community-based projects. Fair trade also purports to engender global solidarity through linking Southern producers and Northern consumers in a concerted effort to direct the market towards social aims. The paper examines the strengths and weaknesses of fair trade as a social welfare intervention. Recommendations are provided to strengthen the fair-trade movement in light of social work values.
\end{abstract}

Keywords: Fair trade, community development, cooperatives, social development

In 2009, 110 million pounds of coffee were certified with a mark in locations across the United States (TransFair USA, 2010). This mark on coffee represents more than a clever marketing tactic; it represents the efforts of Southern coffee-farming communities as well as the efforts of Northern businesses and consumers to challenge unjust global trading relations through fair trade. This paper defines fair trade and examines the imperfect global trading relations that provided impetus for the movement. The paper then turns to the evidence that fair trade provides a number of benefits to producers, cooperatives, and coffee-farming communities. Next, the paper draws attention to the growing body of critical literature that suggests that fair trade does not deliver what it promises. Finally, the paper considers how social work can contribute to the fair-trade movement to ensure that it delivers what it promises.

\section{FAIR TRADE DEFINED}

The term fair trade signifies more than establishing a higher price for certain goods than free-trade mechanisms would prescribe; it is more than "we pay more/they get more" (Ronchi, 2002, p. 1). Fair trade has been touted as a tool of sustainable development, a global community capacity-building project, a social capital cultivator, and a civil society strategy to alleviate rural poverty in the Global South, and a transnational advocacy movement. Fair trade encourages communities in the South to become protagonists in their own development by engaging in just trading arrangements with Northern businesses. Thus, fair trade operates as a community development initiative on two levels. On the one hand, fair trade defines community as a territorially specific entity. Fair trade requires that producing communities employ sustainable development practices and are compensated for doing so. Additionally, fair trade defines community broadly as global citizenship. As a global unit, the fair-trade discourse attempts to bridge the spatial and social distances between the North and the South, geopolitical terms used to loosely signify the distinction between developed nations (many of which are in the Northern Hemisphere) and developing nations (many of which

Charity Samantha Fitzgerald, MA, is a doctoral candidate in the School of Social Welfare at the University of California, Berkeley.

Copyright (C) 2012 Advances in Social Work Vol. 13 No. 2 (Summer 2012), 375-390 
are in the Southern Hemisphere), respectively. This paper makes references to both the local and the global constructs of community.

The most commonly cited definition of fair trade comes from the European Fair Trade Association (2006), which notes the following:

Fair Trade is a trading partnership, based on dialogue, transparency and respect, that seeks greater equity in international trade. It contributes to sustainable development by offering better trading conditions to, and securing the rights of, marginalized producers and workers - especially in the South. Fair Trade organizations (backed by consumers) are engaged actively in supporting producers, awareness raising and in campaigning for changes in the rules and practice of conventional international trade (p. 1).

Fair trade makes demands of traders, a collective term that Nicholls and Opal (2005) use to refer to importers, exporters, and manufacturers, and of producers. Of traders, the fair-trade movement requires they adequately compensate producers for their crops and their goods (Sick, 2008a). The established price ostensibly reflects the summation of three costs: (1) the cost of production (which includes social and environmental externalities), (2) the cost of living, and (3) the cost of complying with fair-trade standards (Nicholls \& Opal, 2005). If the free-trade price rises above the fair-trade floor price, which is $\$ 1.40 / \mathrm{lb}$ for coffee Arabica (washed), traders are to pay the free-trade price in addition to the social premium (Fairtrade Labelling Organization, 2011b). The social premium for coffee amounts to $\$ 0.20 / \mathrm{lb}$ (Fairtrade Labelling Organization, 2011b). Second, fair-trade practices involve a long-term commitment of traders to producers (Sick, 2008a). These long-term relationships lower transaction costs for producers since they do not have to continually search for someone to whom to sell their coffee. Additionally, because of these long-term relationships, traders are to provide producers up to $60 \%$ of the invoice prior to product delivery if requested (Nicholls \& Opal, 2005). Third, traders are to provide technical support to producers to enable them to increase their production capacities and to encourage environmentally sustainable practices. Finally, traders are committed to consumer education in the Global North, thereby raising social awareness and increasing the market for fair-trade goods (Sick, 2008b).

Of producers, fair trade demands that they be organized into democratic cooperatives that utilize environmentally sustainable practices. It is believed that cooperative organization increases collective bargaining power vis-à-vis large buyers (Sick, 2008a), thereby engendering empowerment (Milford, 2004). It is also reported that having a voice in the decision-making processes of the cooperative encourages social inclusion of marginalized groups, such as women. The aforementioned social premium paid by traders is to be earmarked and allocated democratically by cooperatives for community projects, such as health and education initiatives. Environmentally sustainable practices constitute another requisite for fair-trade producers (Sick, 2008a). Environmentally sustainable practices do not necessarily signify organic coffee farming, although sometimes products are both fair-trade and organically certified. Environmentally sustainable practices match innovative technology with rural realities. Farmers in Costa Rica, for example, have experimented with two alternative sources of power: solar and 
methane from cow manure (Sick, 2008b). The majority of producers belonging to fairtrade cooperatives must be small-scale farmers. The Fairtrade Labelling Organization (2009) defines small-scale farmers as those who are not "structurally dependent" on hired labor (p. 4). Child labor that interferes with school attendance or educational attainment is not permissible (Fairtrade Labelling Organization, 2009). Finally, producers are to aim for gender equity in all activities and organizations (Fairtrade Labelling Organization, 2009).

This paper focuses specifically on fair-trade coffee. Coffee has been the driving force behind the fair-trade movement. In fact, of all commodities-whether freely or fairly traded-coffee is the second most valuable commodity exported by developing countries (Talbot, as quoted in Pendergrast, 2009). Within the fair-trade movement, coffee sales are greatest in value of any commodity (Nicholls \& Opal, 2005). Coffee meshes well with fair-trade principles because of the requirement that production operations be small scale. Coffee is a crop that is conducive to small-scale farming, and this quality is reflected by the fact that small-scale producers grow $70 \%$ of the world's coffee (Bacon, 2005). Another reason to explain the intimate connection between fair trade and coffee is that at the time of the fair-trade explosion in the 1990s and the 2000s, coffee farmers were receiving historically low prices, the lowest prices since 1882, to be precise, for their crop (Fridell, 2004). Coffee producers experienced net losses several years in a row, and international nongovernmental organizations (NGOs) took note of the dire poverty in coffee-growing regions. It was estimated that the coffee crisis affected up to 125 million people (Murray, Raynolds, \& Taylor, 2003). Thus, coffee became the ideal fair-trade commodity.

Today certified fair-trade goods (including, but not limited to, fair-trade coffee) constitute a hot market. In spite of a global recession, sales have continued to increase during each of the past 4 years (Fairtrade Labelling Organization, 2011a). At the end of 2010, there were 905 producer groups in the Global South affiliated with the fair-trade movement (Fairtrade Labelling Organization, 2011a). These groups employed 1.2 million workers, meaning that the total number of direct beneficiaries is about 6 million people accounting for workers' family members (Fairtrade Labelling Organization, 2011a). The social premium paid to producer groups in 2010 totaled $€ 51.5$ million (about $\$ 70$ million) (Fairtrade Labelling Organization, 2011a).

Thusly described, fair trade appears to offer a promising way for producers and consumers to challenge conventional market mechanisms. For coffee producers in the Global South, fair trade offers a way to manage risk. For businesses and consumers in the Global North, fair trade offers a way to express solidarity with producers. The next section turns to the global conditions, namely unfair trading relations and the endemic failures of the free market that gave rise to the fair-trade movement. 


\section{FAIR TRADE: A CHALLENGE TO UNJUST GLOBAL TRADING RELATIONS}

In the 1960s, there was an emerging theoretical argument that trade agreements were often crafted on terms unfavorable to countries in the Global South, which exacerbated inequality and poverty. Brown (2006) reported that those often perceived to be "left behind" were actually well integrated into global trade agreements. It was believed that the terms of trade, not the lack of trade, created the conditions for certain countries to be left behind and to share inequitably in the distribution of global wealth. The world had been divided into rich and poor, remarked Barratt Brown (1993) in his groundbreaking fair-trade text, and trade had driven the wedge between the two regions. Thus, an intellectual underpinning of fair trade stems from dependency theory, a body of literature that argues that resources are directed from the Global South to the Global North, thereby relegating the former to a persistent condition of so-called underdevelopment.

The deconstruction of free-trade theory and the assertion that it cannot deliver what it promises deepened the theoretical underpinning of fair trade. Michael Barratt Brown noted that rural producers do not benefit from free trade because several market failures are endemic to the free-trade system and that the neoliberal assumption of a level playing field is erroneous. These market failures are the norm rather than the exception. He blamed market failures on large transnational companies that dominate agricultural markets because they have access to finance, and they can easily switch from one supplier to another. In the coffee industry, five transnational companies controlled $69 \%$ of the instant and roasted markets, and eight exporting companies controlled $56 \%$ of the coffee trade in 1998, whereas an estimated 20 to 25 million families were involved with its production (Bacon, 2005). Trading power is concentrated; producing power is dispersed. Given the concentration of trading power in the hands of a few, traders stand at a negotiating advantage over producers (Nicholls \& Opal, 2005). Transnational companies also control most of the value-adding processes, specifically roasting, which means that coffee farmers only receive about $2 \%$ of the value of a cup sold in a coffee shop (Petchers \& Harris, 2008). Thus, the political economy of coffee production and consumption seems to offer terms that are more favorable to traders in the North than to the producers in the South.

In addition to the market distortions introduced by the concentrated power of traders, Hutchens (2009) notes additional market failures that small-scale producers face, such as a lack of market access (or access through coyotes who cut into the profits of producers), imperfect information about markets (which is often distorted by coyotes who are looking to maximize profit), lack of access to financial markets and credit, and an inability to switch to other sources of income generation. Fair trade attempts to draw trade theory and trade practice together by correcting for these market failures (Nicholls \& Opal, 2005).

The fair-trade movement, as discussed in the first section, attempts to help local communities confront global market conditions as discussed in this section. However, how does fair trade operate at the grassroots level? Are fair-trade practices and fair-trade discourses congruent? The next two section addresses this question. 


\section{FAIR TRADE: STRENGTHS AS A COMMUNITY DEVELOPMENT INITIATIVE}

Fair trade focuses on capacity building at the local level and on helping cooperatives integrate into the global economy on just terms. Because of its development focus, fair trade is claimed to be a long-term strategy to alleviate poverty rather than a mere stopgap aid measure. A critical review of the literature reveals three broad categories of fair-trade beneficiaries: producers, cooperatives, and communities.

Fair-trade producers receive steady income in contrast to reliance on the volatile conventional market (Kohler, 2006; Macdonald, 2007; Murray, Raynolds, \& Taylor, 2006). Even though they often cannot sell the entirety of their crop to fair-trade markets (Kohler, 2006), receiving at least a partial guaranteed salary created a sense of economic security (Taylor, 2002; Kohler, 2006; LeMare, 2008; Bacon, 2005; Utting-Chamorro, 2005; Nicholls \& Opal, 2005), which can obviate the need for migration (Taylor, 2002; LeMare, 2008), although one study (Jaffee, 2007) found that migration among fair-trade producers was equivalent to that of conventional-market producers due to the "healthy migrant” selection bias.

Estimates of how much more fair-market producers receive than conventional-market producers range from $10 \%$ (Macdonald, 2007) to 40\% (Raynolds, 2002) to $100 \%$ (UttingChamorro, 2005). With the increased income, producers can keep their children in school (Lyon, 2007; Macdonald, 2007; Murray et al., 2006; Nicholls \& Opal, 2005; Ruben, Fort, \& Zuniga-Arias, 2009; Taylor, 2002; Utting-Chamorro, 2005), repay debts (Lyon, 2007), maintain and improve homes and farms (Lyon, 2007; Macdonald, 2007; Raynolds, Murray, \& Taylor 2004; Ruben, Fort, \& Zuniga-Arias, 2009; Utting-Chamorro, 2005), improve the quality of coffee grown (Murray et al., 2006; Taylor, 2002), access credit (Murray et al., 2003), access training (Murray et al., 2003) and consume adequate diets (LeMare, 2008; Utting-Chamorro, 2005). These differences are reflective that fair-trade producers are able to invest in assets that will provide security over the long term (Ruben, Fort, \& Zuniga-Arias, 2009). They can also use the increased income to hire other laborers, which benefits others in the community (Ruben et al., 2009; Taylor, 2002). On a final note, producers have also reported higher self-esteem (Nicholls \& Opal, 2005; Raynolds et al., 2004; Taylor, 2002).

A requirement of fair trade is that communities in the Global South be organized into democratically managed cooperatives in order to participate. The idea is that a group of producers is more powerful than a single producer and that there are advantages in pooling resources. Together, it is believed that community members are more effective at solving common problems than individuals' unlinked efforts (DeCarlo, 2007). Additionally, it is believed that combined efforts not only are more effective at solving problems but also at opening opportunities (DeCarlo, 2007). The invocation of the cooperative conjures such buzz terms as participation, empowerment, capacity building, social capital, and solidarity.

Fair trade promotes community cohesion and coordination through cooperative strengthening. It is noted that fair trade does not set up cooperatives but rather works with 
already existing cooperatives and strengthens those cooperatives. Researchers note that fair trade has perhaps had the greatest impact at the cooperative level as it strengthens their organizational capacities to supplement functions and services inadequately provided by the state (Jaffee, 2007; Macdonald, 2007; Ruben, Fort, \& Zuniga-Arias, 2009; Simpson \& Rapone, 2000; Taylor, 2002; Taylor, Murray, \& Raynolds, 2005; Utting-Chamorro, 2005). Participation in fair trade ensures a degree of economic stability for cooperatives based on the promises of a floor price and a long-term commitment. By increasing the capacities of cooperatives, they can fulfill and multiply their roles in the community, such as providing credit to members at low interest rates (Renard \& PerezGrovas, 2007). Also, cooperatives have deepened their involvement with the coffee trade to extend vertically up the commodity chain, thereby capturing more of the profits associated with value-added processes. Strong cooperatives have been able to construct processing facilities. They have also been able to expand into other niche markets, such as organic (LeMare, 2008; Taylor, 2002). Participation in a cooperative associated with fair trade also enables producers to pool resources through sharing transportation costs, thereby benefiting from economies of scale (Utting-Chamorro, 2005). Integration into fair trade provides cooperatives with access to information about recent market trends and technological innovations, thus attempting to ameliorate a persistent market failure noted earlier.

Beyond the economic strengthening afforded by fair-trade certification, there are also social and networking implications for fair-trade cooperatives. Looking downward, being fair-trade certified enhances perceptions of the cooperative's legitimacy to members (Raynolds et al., 2004; Ruben, Fort, \& Zuniga-Arias, 2009). Looking within, cooperative involvement thickens the social capital of the members (Mendez, 2002; Rice, 2001; Simpson \& Rapone, 2000). Looking upward, fair-trade-participating cooperatives can connect with other fair-trade-participating cooperatives, thereby creating secondary-level cooperatives that augment advocacy strength (Rice, 2001; Ronchi, 2002; Taylor et al., 2005). Additionally, obtaining fair-trade certification status serves as a signaling function and enables cooperatives to more easily partner with nongovernmental agencies, which can provide additional resources and information (Raynolds et al., 2004; Ruben et al., 2009; Taylor, 2002).

Cooperatives play an important role in administering the social premium towards collective purposes. In coffee, the social premium price associated with a pound of coffee is $\$ 0.20$ (Fairtrade Labelling Organization, 2011b). The social premium is earmarked for social, environmental, and/or economic development programs to be decided democratically by the cooperative. When the social premium was initiated, often it was returned to producers in the form of income. Recently, however, the Fairtrade Labelling Organization has been strongly urging that cooperatives use the premium explicitly for community development projects. This social premium is more attractive to fund community development projects than loans from institutions like the World Bank because it comes with no strings attached. Though several authors noted above that organizational capacity building is the greatest strength of fair trade, others (e.g., Smith, 2009; Nicholls \& Opal, 2005) contend that community development projects executed through the social premium are its most impactful intervention. 
Some of the community development projects refer back to the cooperatives, strengthening their organizational capacity, while others attempt to fill the void left behind in the wake of public and social service retrenchment. Community projects brought about as a result of this social premium include transportation (Simpson \& Rapone, 2000; Taylor, 2002), conversion to organic practices (Raynolds et al., 2004), health services (Raynolds et al., 2004; Simpson \& Rapone, 2000; Utting-Chamorro, 2005), sanitation projects (Raynolds et al., 2004), education and training (Ronchi, 2002; Simpson \& Rapone, 2000; Smith, 2009; Taylor, 2002; Utting-Chamorro, 2005;), investment in women's groups (Taylor, 2002), environmental improvements (Nicholls \& Opal, 2005; Ronchi, 2002; Taylor, 2002; Utting-Chamorro, 2005), construction of warehouses and other cooperative facilities (Smith, 2009), and ecotourism (UttingChamorro, 2005).

Fair-trade literature often uses the terms community and cooperative interchangeably. Some community members are not cooperative members. The literature that acknowledges that the terms cooperative and community are not necessarily synonymous still purports that both cooperative strengthening and the social premium provide benefits not just for fair-trade producer participants but also have positive externalities from which non-cooperative members benefit. That is, not all community members might be members of fair-trade cooperatives, yet all receive the benefit of these community projects via the multiplier effect (Daviron \& Ponte, 2005; Lyon, 2007; Nicholls \& Opal, 2005; Ruben et al., 2009). Non-cooperative members, for example, can use the market information provided by fair-trade cooperatives as a bargaining advantage with the coyotes. The provision of information regarding environmentally friendly practices, such as organic farming, is also transferable to non-cooperative members through the demonstration effect.

In sum, fair trade is about strengthening local organizations, thickening social capital, and addressing a locality's needs comprehensively. It helps local communities manage unjust global trading terms and to be actively involved in creating a more just global trading order.

\section{FAIR TRADE: WEAKNESSES AS A COMMUNITY DEVELOPMENT INITIATIVE}

When implemented, DeNeve, Luetchford, and Pratt (2008) suggest that the moral framework of fair trade can be distorted, thus leading to unanticipated outcomes. In general, this critique asserts that community is often portrayed as being unproblematized and unitary, which leads to outcomes that do not mirror what fair-trade discourses purport. Specifically, fair trade does not engage with or affect all community constituents in the same way. It is important to acknowledge the heterogeneity within communities. Additionally, fair trade as a development project has varying degrees of success, depending on whether development is defined in terms of process or outcome.

Fair trade interjects the possibility of the reinforcement, exacerbation, and/or the production of community splintering, and the fair-trade discourse whitewashes over the potential production of stratification. There are two concrete examples that illustrate 
community stratification, one relating to gender and the other to class. The first illustration of strained relations within a community relates to gender equity. Nowhere does fair-trade rhetoric describe exactly what is meant by the term gender equity. This paper contends that gender equity as a fair-trade goal has intentionally been left nebulous to retain symbolic value. It is difficult to discern whether gender equity in fact is achieved through fair trade since there is no standard to which to compare it. Nevertheless, this paper suggests that gender equity, however defined, is not being brought about by fair trade.

Prima facie, fair trade as a development initiative perpetuates an agriculturally reliant local economy, one that men tend to dominate (Murray et al., 2006). Sick's (2008b) ethnographic research in Perez Zeledon, Costa Rica, explores women's tenuous connection to coffee production. Her research suggests that strengthening the role of coffee in the local economy is likely to increasingly distance women from household income-generating activities, thereby reinforcing their traditional household roles. Land, notes Sick, is unevenly distributed between men and women. Due to cultural norms, men are the primary purchasers of land. Purchasing, however, is not the main practice through which land is acquired in Costa Rica. Land has grown increasingly scarce in Costa Rica, and thus it is mainly obtained through inheritance. Even though legislation mandates that land be passed down equitably among sons and daughters, in practice sons are the main inheritors of land. Given few employment opportunities apart from agriculture in rural Costa Rica, whoever owns land controls the purse strings of household finances. Thus, promoting the perpetuation of coffee production prima facie privileges a labor activity in which women are not key actors.

Lyon (2010) concurs that traditionally male agricultural activities are privileged through fair trade over other non-farm income-generating activities where women might play important roles. In an article published in 2008, she describes the inner-workings of a cooperative in Guatemala. In this cooperative, a majority of the members were men. To be specific, only 7 of the 116 members were women (p. 262). As an implicit social norm, these seven women almost never spoke during cooperative meetings (a claim that Lyon buttressed by noting the shushes a woman received when she spoke). In fact, Lyon notes that women's main participation in cooperative meetings was to serve lunch. No women have ever served on the board of the cooperative that Lyon researched. She suggests that their participation in a leadership capacity is impeded both by social norms and by the demands of household duties. In contrast, $77 \%$ of the 53 surveyed cooperative members (a sample that included 5 of the 7 women members) have served on the board. As such, the strengthening of cooperatives reinforces men's roles vis-à-vis those of women, thus undermining the purported fair-trade goal of gender equity (Fort \& Ruben, 2008a).

Lyon (2008) also makes note of the one-family, one-vote policy of many cooperatives throughout Latin America, such as the one she studied. Because of patriarchal customs, the men often get to cast the one vote to represent the family. Even though cooperatives might be complying with the fair-trade requirement of democratic processes (another purported fair-trade goal), this particular democratic practice might undermine gender equity. Lyon's account of women's marginalization within the cooperative is buttressed by other similar accounts (Fridell, 2007; Ronchi, 2002; Utting- 
Chamorro, 2005). Thus, fair-trade practices relating to gender equity at times do not map onto fair-trade discourse.

The second example of community stratification within community relates to the treatment of landless laborers. Fair-trade discourses do not fully address the class differences and the concomitant power imbalances between small-scale producers, and landless laborers. Fair trade as it relates to coffee production keeps the landless laborer invisible. Jaffee (2007) notes that often fair-trade farmers must hire day laborers to comply with the labor-intensive, environmentally mindful practices prescribed by fairtrade certification processes. There are no specifications regarding the compensation of landless laborers employed by small-scale producers. Landless laborers are given short shrift in fair-trade discourses, yet they are active participants in fair trade. For example, Luetchford (2008b) critiques Sick's ethnographic work in Costa Rica. Sick briefly notes that during coffee harvesting season about $25 \%$ of family farmers, a sizeable percentage, will contract with landless laborers. Nevertheless, she mentions this only as an aside. She focuses instead on the small-scale producer. Fair-trade studies make few commentaries of how and/or if landless laborers benefit from fair trade aside from the community projects, such as road maintenance, that benefit all community members irrespective of their affiliation or lack thereof with the cooperative. Though landless laborers might benefit from the community projects via the multiplier effect, they do not get a voice with regards to which community projects are realized. Thus, the concerns that are most pressing to them might not be addressed.

There also seems to be a gap between discourse and practice in terms of the social premium. Fair trade claims that decisions regarding what to do with social premiums are to be determined through a democratic, inclusive process. Nevertheless, producers seem strangely unaware of the existence or the use of a social premium. In one cooperative (Fort \& Ruben, 2008b), over 10\% of producers were unaware of the existence of the social premium. In this same study, only $23 \%$ claimed to have derived any benefit from the premium. In an evaluative study of banana production (Zuniga-Arias \& SaenzSegura, 2008), $71 \%$ of respondents said they had not been consulted about the use and the allocation of the social premium. Ronchi (2002), too, reported the odd finding that, in spite of the perceived sense of augmented community welfare, cooperative-affiliated producers did not link the positive outcome to fair trade. In fact, they seemed unaware of fair trade. Again, there appears to be a gap between fair trade's inclusive community construct and what unfurls on the ground.

These critiques of the rosy portrayal of cohesive, inclusive communities also have implications for the conceptualization and the operationalization of development within local communities. At times, the certification standards seem to be at odds with each other. The one-family, one-vote policy employed by many cooperatives upholds the standard of democratic processes but without thorough consideration as to how it can undermine gender equity. In the case of environmental standards, the need to adhere to certain labor-intensive criteria is privileged without robust consideration as to how landless laborers should be compensated and treated. The emphasis on implementing community projects also comes at the expense of educating producers about the facets of fair trade. Neither gender equity and democratic processes, nor just compensation and 
environmental standards, nor community projects and extensive community participation are inherently contradictory. Rather, because they have not been adequately conceptualized and operationalized, in practice these standards can undermine each other.

Examining fair trade at the meso level, fair trade must exclude certain communities from participation. The requisites are such that only well organized communities, often those that already have flourishing cooperatives, can participate. Because of the cooperative requisite, the most disadvantaged communities are excluded from participation in fair trade. Communities are also intentionally excluded from certification because the fair-trade market cannot absorb all goods that are produced for it. In the coffee segment, for example, often only $20 \%$ to $25 \%$ of fair trade farmers' coffee is sold on the fair-trade market (Jaffee, 2008). Elsewhere, Goodman (2008) reported that the export capacity of fair-trade producers is seven times that of fair-trade sales. Fair-trade producers must sell the remaining portion on the conventional market. To control fairtrade supply, the fair-trade certification bureaucracy has been reticent to certify more cooperatives. The discursive project of fair trade obscures these slippages of inclusion and exclusion.

The whitewashing of inclusion and exclusion becomes even more salient at the macro level. As global citizenship, fair trade uses language such as stakeholders and partners. Even framing fair trade as an intervention is eschewed for terms like collaboration. Mere rhetorical slight, however, does not make for good practice. Though the propagators of fair-trade discursive practices in the North claim that the project embodies trade not aid, some participating producers in the South perceive the project quite differently. In fact, some Southern small-scale producers, such as those in Ronchi's (2002) study, seem to understand fair trade only in terms of augmented income and not as global solidarity. Moreover, emerging research suggests that producers have perceived a need to protect themselves from fair trade, which has been attributed to the relatively recent introduction of certification schemes that disrupt local social norms through their surveillance mechanisms (Wilkinson \& Mascarenhas, 2007).

The certification system designed to scale up fair trade perhaps has undermined the pursuit of key movement values, such as trust and solidarity. The certification system has institutionalized imbalances in power by creating non-democratic, top-down decisionmaking structures (Hutchens, 2009). In this nascent bureaucratic structure, traders have had more voting power than producers in determining the course of fair trade (Murray et al., 2003). In fact, it was only recently that producers were promoted from observer status to having 4 representatives on the newly expanded 14-person board of the Fairtrade Labelling Organization (Jaffee, 2007). Producers have reported feeling that their presence is merely symbolic rather than substantive (Renard \& Perez-Grovas, 2007) and that certification standards are largely determined by the Northern stakeholders (Luetchford, 2008a).

Southern producers have also expressed disenchantment with other facets of fair trade. For example, some have reported wanting more access to information about Northern markets (Wilkinson \& Mascarenhas, 2007). Though fair trade claims to ameliorate the endemic market failure of imperfect information, some producers feel that 
they are only given certain information that continues to relegate them to the position of aid recipients rather than being trade partners. Producers have also reported feeling ignorant about what happens to their products (Renard \& Perez-Grovas, 2007), and they have expressed a desire for more communication with Northern consumers (Murray et al., 2003). Though elaborate marketing schemes discussed above provide information to Northern consumers about Southern producers, information does not flow in the reverse direction. Finally, producers have expressed disgust with certification criteria and fees, which are perceived as being unduly. Mutersbaugh (2002) goes so far as to liken certification criteria to ecological neocolonialism. Some producers perceive a dearth of opportunities to express their disgust. When they do voice their frustrations, they report a lack of responsiveness by the fair-trade labeling regime.

In short, rather than challenging and transforming the market, parts of the fair-trade movement seem to have been absorbed by it to the point that producers report that there is very little that is alternative about the fair-trade market (Zuniga-Arias \& Saenz-Segura, 2008). In so doing, some producers have experienced fair trade as yet another practice of marginalization. Write Kruger and du Toit (2007), "The prospect continually exists that Fair Trade, far from being a way of challenging the power imbalances between North and South, can function as a way of commodifying political concern and deflecting challenge, renormalizing consumption and legitimizing a 'kinder, gentler' food regime that is perhaps more paternalistic and less nakedly exploitative” (p. 215). The certification system reflects and reproduces the disconnect between fair-trade discourse and practices. The focus on scaling up the fair-trade movement through the certification scheme perpetuates power imbalances albeit in subtle, gentle terms.

The preceding critique of fair trade is not meant to diminish all confidence in the community development initiative. This author concurs with Lyon's (2006) assessment that although the fair-trade system is imperfect, it should not be discarded given few (if any) alternatives to just trade relations. Rather, fair trade can be strengthened as a local and global community development initiative, perhaps with support from social workers, through robust consideration of the critiques presented above. Thus, the paper concludes with several suggestions that might give due consideration to the constructs of community and development as they pertain to fair trade.

\section{POTENTIAL SOCIAL WORK CONTRIBUTIONS TO FAIR TRADE}

The certification system is not inherently bad. It has been credited with expanding the market for fair trade by placing goods in places that consumers frequent. However, the certification system can be tweaked to maximize fair trade's potential to help local communities contend with global trading. The certification system can be made more participatory from the micro to the macro level, and social workers can engender robust participation across levels. First, when certifiers visit fair-trade cooperatives, they can speak with a vast cross-section of producers and community members including women and landless members to ensure that all community members, not merely those preselected by cooperative management, are given a voice. The Fairtrade Labelling Organization can also be more proactive in helping producers address the concerns raised by the cross-section of community members. Being attentive to various dimensions of 
diversity, social workers in local communities can ensure that no one is excluded from participating. Participatory evaluation and collaborative problem-shooting can also serve to clarify certification standards, which hopefully would give producers a stronger position from which to negotiate the standards set forth by the Fairtrade Labelling Organization on the macro level. Creating more participatory processes might make fair trade more messy, and it might expose unflattering aspects of fair-trade practice. Nevertheless, it serves to focus on making community into an inclusive construct, and it highlights the potential of development as both a process and an outcome. In sum, participatory evaluation, in which many social workers have experience facilitating, can also serve to align fair-trade practices with fair-trade discourses.

Fair trade might also be strengthened by breaking down dichotomies. One such dichotomy is the one that exists between consumers and producers. This dichotomy can be eroded by encouraging countries in the Global South to form their own fair-trade labeling national initiatives so that inhabitants of the South can become consumers. Northern fair-trade labeling initiatives can also consider certifying producer groups within their selfsame region so that Northern workers, too, can become fair-trade producers. Commixing consumer and producer status serves to breakdown the historical relations established by colonialism. The recent certification of South Africa as both a consuming and producing nation is a step towards eroding binaries. As advocates, social workers can consider pressuring FLO to consider continuing to revise these purchasing and consuming limitations.

The provision of comprehensive information can also serve to erode binaries. Northern participants can be provided multi-dimensional information about producers and producing communities. Complex information does not make for friendly marketing sound bytes, but portraying fair-trade Southern participants as unidimensional producers in "ethnic" apparel on marketing ploys serves to reify the Other rather than to create genuine global solidarity. Additionally, Southern producers can be given more information about Northern consumers and Northern markets so that information flows bidirectionally (or, even better, multilaterally if the rigid North-South, consumerproducer binary were to be eroded). Advocating for the provision of information in both the North and the South reflects social work's commitment to self-determination.

In the fair-trade movement, the present-day is a point of inflection. The movement is at a juncture that exposes the contradictions between fair-trade discourses and fair-trade practices (Fisher, 2009). Rather than representing the demise of the movement, these growing pains are an opportunity for reflection and action. And in spite of the growing pains experienced by the movement, fair trade sales have not only weathered the recession, but have even expanded in the face of it (Fairtrade Labelling Organization, 2011a). Fair-trade organizations are looking to broaden and to deepen the movement. Expansion into new markets and the deepening of existing markets have increasingly required institutionalization (Doane, 2010). What is needed is reflective research and action that informs the institutionalization to ensure that fair-trade discourses and fairtrade practices map onto each other and that the movement reaches its maximum potential. It is hoped that these critiques as facilitated by social workers and other allies will serve to shape the present point of inflection. 


\section{References}

Bacon, C. (2005). Confronting the coffee crisis: Can fair trade, organic, and specialty coffees reduce small-scale farmer vulnerability in Northern Nicaragua? World Development, 33(3), 497-511.

Barratt Brown, M. (1993). Fair trade: Reform and realities in the international trading system. New Jersey: Zed.

Brown, S. (2006). Myths of free trade: Why American trade policy has failed. New York: New Press.

Daviron, B., \& Ponte, S. (2005). The coffee paradox: Global markets, commodity trade, and the elusive promise of development. New York: Zed Books.

DeCarlo, J. (2007). Fair trade: A beginner's guide. Oxford: Oneworld.

DeNeve, G., Luetchford, P., \& Pratt, J. (2008). Introduction: Revealing the hidden hands of global market exchange. In G. DeNeve, P. Luetchford, \& J. Pratt (Eds.) Hidden hands in the market: Ethnographies of fair trade, ethical consumption, and corporate social responsibility (pp. 1-30). Bingley, United Kingdom: Emerald.

Doane, M. (2010). Relationship coffees: Structure and agency in the fair trade system. In S. Lyon \& M. Moberg (Eds.), Fair trade and social justice: Global ethnographies (pp. 229-257). New York: New York University Press.

European Fair Trade Association. (2006). EFTA: Joining fair trade forces. Retrieved from www.european-fair-trade-association.org/efta/Doc/What.pdf

Fairtrade Labelling Organization. (2009). Generic fairtrade standards for small producers' organizations. Retrieved from http://www.fairtrade.net/654.html

Fairtrade Labelling Organization. (2011a). At a glance. Retrieved from http://www.fairtrade.net/fileadmin/user_upload/content/2009/resources/201110_Fairtrade_At_a_Glance-EN.pdf

Fairtrade Labelling Organization. (2011b). Fairtrade minimum price and fairtrade premium table. Retrieved from www.fairtrade.net/standards.html

Fisher, E. (2009). Introduction: The policy trajectory of fair trade. Journal of International Development, 21, 985-1003.

Fort, R., \& Ruben, R. (2008a). The impact of Fair Trade on banana producers in Northern Peru. In R. Ruben (Ed.), The impact of fair trade (pp. 49-74). The Netherlands: Wageningen Academic Publishers.

Fort, R., \& Ruben, R. (2008b). The impact of fair trade certification on coffee producers in Peru. In R. Ruben (Ed.), The impact of fair trade (pp. 75-98). The Netherlands: Wageningen Academic Publishers.

Fridell, G. (2004). The fair trade network in historical perspective. Canadian Journal of Development Studies, 25(3), 411-428. 
Fridell, G. (2007). Fair trade coffee: The prospects and pitfalls of market-driven social justice. Toronto: University of Toronto Press.

Goodman, D. (2008). The international coffee crisis: A review of the issues. In C. M. Bacon, V. E. Mendez, S. R. Gliessman, D. Goodman, \& J. A. Fox (Eds.), Confronting the coffee crisis: Fair trade, sustainable livelihoods and ecosystems in Mexico and Central America (pp. 3-25). Cambridge, MA: MIT Press.

Hutchens, A. (2009). Changing big business: The globalization of the fair trade movement. Northampton, MA: Edward Elgar Publishing.

Jaffee, D. (2007). Brewing justice: Fair trade coffee, sustainability, and survival. Berkeley, CA: University of California Press.

Jaffee, D. (2008). 'Better, but not great': the social and environmental benefits and limitations of Fair Trade for indigenous coffee producers in Oaxaca, Mexico. In R. Ruben (Ed.), The impact of fair trade (pp. 195-222). The Netherlands: Wageningen Academic Publishers.

Kohler, P. (2006). The economics of fair trade coffee: For whose benefit? HEI Working Paper No. 06/2007. Retrieved from http://repec.graduateinstitute.ch/pdfs/Working_papers/HEIWP06-2007.pdf

Kruger, S., \& du Toit, A. (2007). Reconstructing fairness: Fair Trade conventions and worker empowerment in South African horticulture. In L. T. Raynolds, D. Murray, \& J. Wilkinson (Eds.), Fair trade: The challenges of transforming globalization (pp. 200-220). New York: Routledge.

LeMare, A. (2008). The impact of fair trade on social and economic development: A review of the literature. Geography Compass, 2(6), 1922-1942.

Luetchford, P. (2008a). Fair trade and a global commodity: Coffee in Costa Rica. Ann Arbor, MI: Pluto Press.

Luetchford, P. (2008b). The hands that pick fair trade coffee: Beyond the charms of the family farm. In G. DeNeve, P. Luetchford, \& J. Pratt (Eds.) Hidden hands in the market: Ethnographies of fair trade, ethical consumption, and corporate social responsibility (pp. 143-170). Bingley, United Kingdom: Emerald.

Lyon, S. (2006). Evaluating fair trade consumption: Politics, defetishization, and producer participation. International Journal of Consumer Studies, 30(5), 452-464.

Lyon, S. (2007). Fair trade coffee and human rights in Guatemala. Journal of Consumer Policy, 30, 241-261.

Lyon, S. (2008). We want to be equal to them: Fair-trade coffee certification and gender equity within organizations. Human Organization, 67(3), 258-268.

Lyon, S. (2010). A market of our own: Women's livelihoods and fair trade markets. In S. Lyon \& M. Moberg (Eds.), Fair trade and social justice: Global ethnographies (pp. 125-146). New York: New York University Press. 
Macdonald, K. (2007). Globalizing justice within coffee supply chains? Fair trade, Starbucks, and the transformation of supply chain governance. Third World Quarterly, 28(4), 793-812.

Mendez, V. E. (2002). Fair trade networks in two coffee cooperatives of western El Salvador: An analysis of insertion. Retrieved from www.colostate.edu/Depts/Sociology/FairTradeResearchGroup/

Milford, A. (2004). Coffee, cooperatives, and competition: The impact of fair trade. Dhr. Michelsen Institute: Development Studies and Human Rights.

Murray, D., Raynolds, L. T., \& Taylor, P. L. (2003). One cup at a time: Poverty alleviation and fair trade coffee in Latin America. Colorado State University: Fair Trade Research Group.

Murray, D. L., Raynolds, L. T., \& Taylor, P. L. (2006). The future of fair trade coffee: Dilemmas facing Latin America's small-scale producers. Development in Practice, 16(2), 179-192.

Mutersbaugh, T. (2002). The number is the beast: A political economy of organic coffee certification and producer unionism. Development and Planning, 34, 1165-1184.

Nicholls, A., \& Opal, C. (2005). Fair trade: Market-driven ethical consumption. Thousand Oaks, CA: Sage.

Pendergrast, M. (2009, April). Coffee second only to oil? Is coffee really the second largest commodity? Tea and Coffee Trade Journal. Retrieved from http://www.entrepreneur.com/tradejournals/article/198849799_1.html

Petchers, S., \& Harris, S. (2008). The roots of the coffee crisis. In C.M. Bacon, V. E. Mendez, S. R. Gliessman, D. Goodman, \& J. A. Fox (Eds.), Confronting the coffee crisis: Fair trade, sustainable livelihoods and ecosystems in Mexico and Central America (pp. 43-66). Cambridge, MA: MIT Press.

Raynolds, L. T. (2002). Consumer/producer links in fair trade coffee networks. Sociologia Ruralis, 42(4), 404-424.

Raynolds, L. T., Murray, D., \& Taylor, P. L. (2004). Fair trade coffee: building producer capacity via global networks. Journal of International Development, 16, 1109-1121.

Renard, M. C., \& Perez-Grovas, V. (2007). Fair trade coffee in Mexico: At the center of the debates. In L. T. Raynolds, D. Murray, \& J. Wilkinson (Eds.), Fair trade: The challenges of transforming globalization (pp. 138-156). New York: Routledge.

Rice, R. (2001). Noble goals and challenging terrain: Organic and fair trade coffee movements in the global marketplace. Journal of Agricultural and Environmental Ethics, 14, 39-66.

Ronchi, L. (2002). The impact of fair trade on producers and their organizations: A case study with Coocafe in Costa Rica. Prus Working Paper No. 11.

Ruben, R., Fort, R., \& Zuniga-Arias, G. (2009). Measuring the impact of fair trade on development. Development in Practice, 19(6), 777-788. 
Sick, D. (2008a). Coffee, farming families, and fair trade in Costa Rica: New markets, same old problems? Latin American Research Review, 42(3), 193-208.

Sick, D. (2008b). Farmers of the golden bean: Costa Rican households, global coffee, and fair trade. DeKalb, IL: Northern Illinois University Press.

Simpson, C. R., \& Rapone, A. (2000) Community development from the group up: Social-justice coffee. Human Ecology Review, 7(1), 46-57.

Smith, A. M. (2009). Fair trade, diversification and structural change: Towards a broader theoretical framework of analysis. Oxford Development Studies, 37(4), 457-478.

Taylor, P. L. (2002). Poverty alleviation through participation in fair trade coffee markets: Synthesis of case study research question findings. Retrieved from http://www.cfat.colostate.edu/research/one-cup-at-a-time/

Taylor, P. L., Murray, D. L., \& Raynolds, L. T. (2005). Keeping trade fair: Governance challenges in the fair trade coffee initiative. Sustainable Development, 13, 199-208.

TransFair USA. (2010). Fair Trade certified coffee: Impact report. Retrieved from http://fairtradeusa.org/node/2007

Utting-Chamorro, K. (2005). Does fair trade make a difference: The case of small coffee producers in Nicaragua. Development in Practice, 15(3/4), 584-599.

Wilkinson, J., \& Mascarenhas, G. (2007). The making of the Fair Trade movement in the South: the Brazilian case. In L. T. Raynolds, D. Murray, \& J. Wilkinson (Eds.), Fair trade: The challenges of transforming globalization (pp. 157-179). New York: Routledge.

Zuniga-Arias, G., \& Saenz-Segura, F. (2008). The impact of fair trade in banana production of Costa Rica. In R. Ruben (Ed.), The impact of fair trade (pp. 117-136). The Netherlands: Wageningen Academic Publishers.

\section{Author note:}

Address correspondence to: Charity Samantha Fitzgerald, University of California at Berkeley, 120 Haviland Hall \#7400, Berkeley, CA 94720-7400. Email: sfitzgerald@berkeley.edu 